University of Nebraska - Lincoln

DigitalCommons@University of Nebraska - Lincoln

Faculty Publications, Department of History

History, Department of

2-19-2000

Basel's Rural Pastors as Mediators of Confessional and Social

Discipline

Amy Nelson Burnett

University of Nebraska - Lincoln, aburnett1@unl.edu

Follow this and additional works at: https://digitalcommons.unl.edu/historyfacpub

Part of the History Commons

Burnett, Amy Nelson, "Basel's Rural Pastors as Mediators of Confessional and Social Discipline" (2000). Faculty Publications, Department of History. 18.

https://digitalcommons.unl.edu/historyfacpub/18

This Article is brought to you for free and open access by the History, Department of at DigitalCommons@University of Nebraska - Lincoln. It has been accepted for inclusion in Faculty Publications, Department of History by an authorized administrator of DigitalCommons@University of Nebraska - Lincoln. 


\title{
Basel's Rural Pastors as Mediators of Confessional and Social Discipline
}

\author{
Amy Nelson Burnett \\ University of Nebraska-Lincoln
}

\begin{abstract}
$\mathrm{O}$ VER the last two decades historians of early modern Europe have adopted the paradigm of confessionalization to describe the religious, political, and cultural changes that occurred in the two centuries following the Reformation. ${ }^{1}$ As an explanatory model confessionalization has often been portrayed as the religious and ecclesiastical parallel to the secular and political process of social discipline, as formulated by Gerhard Oestreich. ${ }^{2}$ In its simplest form, the process of confessional and social discipline is depicted as hierarchical and unidirectional: the impulse to discipline and control came from the secular and ecclesiastical authorities, and the laity, particularly the peasants at the bottom of the hierarchy, had little possibility of exerting counterpressures on those seeking to shape their beliefs and behavior. The inevitable result of the disciplinary process was the gradual suppression of popular culture and the imposition of new standards of belief and behavior on the subjects of the territorial state.

This general view of the inevitable nature and course of social and confessional discipline has been challenged by recent studies of popular religion and popular culture. ${ }^{3}$ Scholars such as Robert Scribner in the English-speaking
\end{abstract}

Research for this paper was made possible in part by a grant-in-aid from the Research Council of the University of Nebraska-Lincoln.

1. The idea of confessionalization has been developed by Heinz Schilling and Wolfgang Reinhardt in numerous articles; see for example Heinz Schilling, "Die Konfessionalisierung im Reich: Religiöser und gesellschaftlicher Wandel in Deutschland zwischen 1555 und 1620," Historische Zeitschrift 246 (1988): 1-45, and Wolfgang Reinhardt, "Zwang zur Konfessionalisierung? Prolegomena zu einer Theorie des konfessionellen Zeitalterst," Zeitschrift für historische Forschung 13 (1983): 257-77. See also the summaries of recent research on confessionalization by Heinrich R. Schmidt, Konfessionalisierung im 16. Jahrhundert, (Munich, 1992) and R. Po-chia Hsia, Social Discipline in the Reformation: Central Europe, 1550-1750 (London, 1989).

2. On Oestreich, see Winfried Schulze, "Gerhard Oestreichs Begriff 'Sozialdisziplinierung in der frühen Neuzeit'," Zeitschrift für historische Forschung 14 (1987): 265-302; Schmidt, Konfessionalisierung, 94-106.

3. On the changes to popular culture in general, the foundational work is Peter Burke, Popular Culture in Early Modern Europe (New York, 1978); see Natalie Zemon Davis's essays on the 
world and Richard van Dülmen in Germany have pointed to the continuities between late medieval popular religious practices and those of early modern Protestantism and have emphasized that change, when it occurred, came only gradually. ${ }^{4}$ In addition, several studies based on the examination of visitation records have cast doubt on the effectiveness of ecclesiastical efforts to induce religious change, although in the English-speaking world the discussion has been distorted by being presented in terms of the "success" or "failure" of the Reformation as a whole. ${ }^{5}$

One aspect of the larger debate on the long-term consequences of the Reformation is the role played by the clergy as mediators of religious and social change. Proponents of confessionalization generally assume that the Protestant and Tridentine Catholic clergy played a prominent role in this process. As representatives of both church and state who lived in daily contact with their parishioners, the pastors were well situated to transmit official norms from those above to those below. As a consequence, the clergy are routinely regarded as willing agents of the secular authority who were largely successful in their efforts to turn their parishioners into obedient subjects. Until fairly recently, however, scholars have paid little attention to how the clergy actually functioned as mediators of official religious and moral norms. ${ }^{6}$ In fact, as Hans-

complexities of early modern popular religion, "Some Tasks and Themes in the Study of Popular Religion," in The Pursuit of Holiness in Late Medieval and Renaissance Religion, Papers from the University of Michigan Conference, ed. Charles Trinkaus and Heiko A. Oberman (Leiden, 1974), 307-36, and idem, "From 'Popular Religion' to Religious Cultures," in Reformation Europe: A Guide to Research, ed. Steven Ozment (St. Louis, 1982), 321-41; see also the work of Robert W. Scribner, as exemplified by his essays collected in idem, Popular Culture and Popular Movements in Reformation Germany (London, 1987). For a discussion of confessionalization, social discipline and their interaction with recent German research on popular culture using the tools of historical anthropology, see Michael Prinz "Sozialdisziplinierung und Konfessionalisier(1) Festellungen in der Sozialgeschichte der frühen Neuzeit" Westfische Forschungen 42 (1992): 1-25.

4. Robert W. Scribner, "The Reformation and the Religion of the Common People," in Die Reformation in Deutschland und Europa: Interpretationen und Debatten, ed. Hans R. Guggisberg, Gottfried G. Krodel, and Hans Füglister (Gütersloh, 1993), 221-42; see also his article "Elements of Popular Belief," with associated bibliography, in Handbook of European History 1400-1600: Late Middle Ages, Renaissance and Reformation, vol. 1, Structures and Assertions, ed. Thom , Jr. Heiko A Oberman, and James D. Tracy (Leiden, 1995), 231-62; Richard van Dülmen, "Volksfrömmigkeit und konfessionelles Christentum im 16. und 17. Jahrhundert," in Volksreligiosität in der modernen Sozialgeschichte, ed. Wolfgang Scheider (Gottingen, 1986), 14-30.

5. Gerald Strauss initiated an intensive controversy in 1975 by asserting that visitation records demonstrate the Protestant reformers' failure to create a Christian society, "Success and Failure in the German Reformation," Past and Present 67 (1975): 30-63; he expanded upon this thesis in the final chater of his book, Luther's House of Learning: Indoctrination of the Young in the Germ Reformation (Baltimore, 1978). On the ensuing debate, see Geoffrey Parker "Success and Failure during the First Century of the Reformation," Past and Present 136 (1992): 43-82.

6. For a discussion of the historiographical debate over the role of the clergy in the process of confessionalization and modernization, see Luise Schorn-Schütte, Evangelische Geistlichkei in der Frühneuzeit: Deren Anteil an der Entfaltung frühmoderner Staatlichkeit und Gesellschaft (Gütersloh, 1996), 20-31.
Christoph Rublack has pointed out, Lutheran pastors faced many difficulties in their relations with their parishioners. Clergy frequently complained about the disrespect shown them by the peasants who comprised their congregations. The pastors' need to accommodate themselves to village norms often limited their ability to act as the representatives of secular authority. ${ }^{7}$ Clearly, further case studies of the clergy at the local level are necessary in order to understand and to evaluate their role as mediators of confessional and social discipline.

An examination of the Protestant pastors and their parishioners in the villages governed by Basel in the century after the Reformation illustrates the challenges faced by the clergy as mediators between the authorities and the peasants. Basel had a relatively small rural territory, which facilitated greater supervision of the rural church by both ecclesiastical and secular officials and closer ties between the urban and the rural clergy than was possible elsewhere in Switzerland. Here, if anywhere, the rural pastors should have functioned effectively as mediators of social and confessional discipline. Their successes and their failures lead us to a more nuanced view of the early modern Protestant clergy than does the traditional hierarchical and unidirectional model described above.

In order to evaluate the effectiveness of Basel's clergy, however, it is necessary to know something about them. Accordingly, in this paper I will look first at the formation of the rural pastoral corps. I will then describe their interactions with their parishioners, focusing particularly on how successful they were in persuading their parishioners to accept and to internalize the new standards of belief and behavior. On this basis I will be able to assess the role played by Basel's rural pastors as mediators of confessionalization.

\section{The Formation of a Protestant Pastoral Corps}

In Basel's efforts to provide its rural parishes with well-trained pastors, the city had two important advantages over its fellow evangelical cities in Switzerland. First, because its territory was small, it did not need to fill a large number of posts. There were only twenty-seven parishes in Basel's rural districts. In contrast, the Zurich church had 116 rural parishes, while Bern, with its large territory, had over $200 .^{8}$ The task of recruiting and training enough pastors for its parish churches was therefore much easier for Basel's church leaders than it was for those in either of the other two cities. Moreover, many of the priests in

7. Hans-Christoph Rublack, “ 'Der wohlgeplagte Priester': Vom Selbstverständnis lutherischer Geistlichkeit im Zeitalter der Orthodoxie," Zeitschrift für historische Forschung 16 (1989): 1-30.

8. The number of Basel's rural parishes actually fluctuated between 27 and 29 between 15291619. On the Zurich church, see Wilhelm Baltischweiler, Die lnstitutionen der evangelisch-reformierten Landeskirche des Kantons Zürich in ihrer geschichtlichen Entwicklung (Zurich, 1904), 17. The first Bern synod in 1530 was attended by 219 pastors; Theodor de Quervain, Kirchliche und soziale Zustände in Bern unmittelbar nach der Einführung der Reformation (1528-1536) (Bern, 1906), 6. 
Basel's rural villages became adherents of the Reformation movement during the 1520s. By the fall of 1528, six months before the official adoption of Protestantism, half of the parishes were already served by clergy who supported the Reformation. ${ }^{9}$ From the early years of the Reformation, then, Basel could rely on a pastoral corps that had a high proportion of clergy committed to the new doctrine, and in succeeding years it was not faced with an overwhelming number of pastoral vacancies that forced it to lower its standards for new pastors.

Basel's second advantage was the presence in the city of a university that provided an established training ground for new pastors. Although the university had closed in 1529 after the official adoption of the Reformation, it was reorganized and reopened in 1532. It took about a generation for the university to rebuild its reputation, but the number of students increased steadily during the second half of the sixteenth century. ${ }^{10}$

Basel's political rulers recognized the importance of providing a university education for a new generation of Protestant clergy. In 1533 the city council established the Collegium Alumnorum with the express purpose of supporting up to twenty-four students who would be trained as pastors and schoolteachers. ${ }^{11}$ The original foundation proved ineffective, however, and twelve years later the Alumneum was reorganized. ${ }^{12}$ The new statutes provided that twelve boys born in Basel or its rural territory would be supported by the city as they prepared for the ministry. Although it was possible for stipendiates to study law or medicine rather than theology, the statutes of the Alumneum allowed this only if the university's rector, its governing board (the Regenz), and the magistrate's representatives agreed. Even the boys' parents were not allowed to withdraw their sons from the Alumneum, once they had given their initial consent, without the approval of the senate. The statutes further specified that stipendiates were to serve Basel after completing their education, and that they could not enter into

9. See Oecolampadius's pastoral letter addressed to the clergy in thirteen of Basel's rural villages and in four in the villages subject to Basel's bishop, Ernst Staehelin, ed., Briefe und Akten zum Leben Oekolampads, zum vierhundertïhrigen Jubiläum der Basler Reformation (Leipzig, 1927-34) 2.239 48. For the background of many of the rural prests and on the spread of the Ref1927-34) 2:239 48. Foll he bakground ormation in Base's el und des Kantons Basel-Landschaft (Liestal, 1932), 1:344-448.

10. Only ten students matriculated in 1541 , but the yearly number of new matriculations increased to a high of 175 in 1580; Rudolf Thommen, Geschichte der Universität Basel, 1532-1632 (Basel, 1889), 87

11. On the Collegium Alumnorum, see Thommen, Geschichte, 75-82; Eberhard Vischer, "Das Collegium Alumnorum in Basel," in Aus fünf jahrhunderten schweizerischer Kirchengeschichte: Zum sechzigsten Geburtstag von Paul Wernle, ed. Theologische Fakultät der Universität Base (Basel, 1932), 95-162.

12. Summarized, with date of 18 March 1545 , in Thommen, Geschichte, 76-77. The new statutes are contained in the Liber Stipendiatorum, Basel Staatsarchiv (henceforth BStA) Universitätsarchiv L 4, fol. 29r-32r. the service, either in church or school, of another governing authority without the city's permission.

In addition to the Alumneum, several students were supported by individual scholarships granted by the university. The first of these scholarships was endowed by Erasmus, who willed a sizable sum to the university to support students enrolled in its four faculties, but the majority of the stipends were established in the last third of the century. Of the thirty-three stipends created before 1624, almost half (15 out of 33) were reserved for theology students. ${ }^{13}$

Although it was not originally required, most of the students who received stipends from the city or the university lived and ate together in one of the two colleges affiliated with the university - the Upper College, located in the former Augustinian convent, and the Lower College, originally housed in the Dominican convent. The statutes for these two colleges, drawn up at about the same time that the Alumneum was reorganized, required that all inhabitants were to be strictly supervised by each college's two directors: the provost, who lived in the college and supervised the students' daily conduct, and the preceptor or coregent, one of the professors from the arts faculty, who was responsible for overseeing their course of study and their morals. ${ }^{14}$ According to the statutes, all inhabitants of each college had to attend the weekday sermons and the two public worship services on Sunday as well as all regularly scheduled lectures, disputations, and declamations prescribed by their teachers. The students swore an oath to accept the statutes before moving into the college, and those who refused to obey them could be expelled and required to reimburse the city for the support that they had already received.

During the 1540s, it was apparently not too difficult for students to evade the obligations imposed by the statutes of the various stipends and the residential colleges. The Basel pastor Johannes Gast complained to a friend that, although stipendiates were supposed to enter the ministry, many chose other career paths instead. ${ }^{15}$ Enforcement of the statutes became more stringent over time,

13. For an analysis of those who received stipends from Erasmus's legacy, including some future Basel pastors; see Lucia Felici, "The Erasmusstiftung and Europe: The Institution, Organization, and Activity of the Foundation of Erasmus of Rotterdam from 1538 to 1600," History of Universities 12 (1993): 25-63. Andreas Staehelin, Geschichte der Universität Basel 1632-1818 (Basel, 1957), 109-13, describes the financial support available to Basel's students in the two centuries after our period. He notes that $3 / 4$ of the individual stipends endowed before 1813 were reserved for citizens of Basel. Since half of these stipends dated from before 1624, it can be assumed that a sizable proportion of the earlier stipends were similarly restricted to Baslers.

14. The statutes of the Upper College were adopted in 1543; those of the Lower College were modeled after those of the Upper College and were adopted in 1547; see the Matricula Superioris Collegii, Handschriftenabteilung, Universitätsbibliothek Basel (henceforth BUB) Mscr A N II 12 , title page and statutes, pp. 1-27; and the Matricula Inferioris Collegii, BUB Mscr A N II 17, title page and statutes, pp. 1-40. The Lower College was later moved to a university building closer to the Upper College.

15. Letter to Conrad Hubert, 4 December 1542, cited in Paul Burckhardt, ed., Das Tagebuch des Johannes Gast: Ein Beitrag zur schweizerischen Reformationsgeschichte (Basel, 1945), 64. 
however. In 1547, the twelve students supported by the city were examined concerning their studies and their career goals; those who did not intend to enter the city's service were deprived of their stipends. ${ }^{16}$ From this time on, records were kept of students supported by the city, and as endowments were made to the university for individual stipends, the names of the recipients were also recorded in a separate book. ${ }^{17}$ Students who violated the statutes were brought to the attention of the rector and the Regenz, and, depending on the seriousness of the charges against them, they could be deprived of their stipends. ${ }^{18}$ Even more effective was the provision that students unwilling to enter the city's service at the end of their education would be required to repay the cost of their stipend. Letters to the rector and the Regenz requesting exemption from this requirement indicate how burdensome potential scholarship students felt this requirement to be. ${ }^{19}$

The generous financial support of the city and the university had the inevitable result of gradually increasing the number of pastors who were both born and educated in Basel. ${ }^{20}$ It took well over a generation, however, before that training produced any noticeable effect on the rural clergy. In 1529, at the official adoption of the Reformation, eight of the twenty-eight rural pastors had matriculated at a university, and three of these had received degrees. Twenty years later the proportions remained virtually unchanged. ${ }^{21}$ By 1569 , however,

16. Liber Stipendiatorum, BStA Universitätsarchiv L 4, pp. 85r-90r.

17. Catalogus Stipendiatorum, BStA Universitätsarchiv L 5.

18. One of the most frequent problems was the unauthorized marriage of students who were receiving stipends. In April of 1550 Johannes Petri lost his stipend for having married withou permission, but he was still held to the obligation to serve the city; BStA Universitätsarchiv B 1, 1 (Acta et Decreta of the Rector and Regenz), 40v. Petri was appointed as deacon in Liestal and schoolteacher in Lausen (the positions were combined) later that year; Karl Gauss, Basilea Reformata: Die Gemeinden der Kirche Basel Stadt und Land und ihre Pfarrer seit der Reformation bis. zur Gegenwart (Basel, 1930), 121

19. See the letter of Theobald Luterburg, 30 August 1604; BStA Universitätsarchiv VII 3 , no.11.

20. The importance of government support for increasing the proportion of locally-born pastors has also been noted in studies of the clergy in Strasbourg by Bernard Vogler, "Recrutement carrière des pasteurs' strasbourgeois au XVI siècle," Revue d'histoire et philosophie religieuses 48 (1968): 151-74; in Kitzingen by Erdmann Weyrauch, "Informationen zum Sozialprofil der evangelischen Geistlichkeit Kitzingens im 16. Jahrhundert," in Ingrid Bátori and Erdmann Weyrauch, Die bürgerliche Elite der Stadt Kitzingen. Studien zur Sozial-und Wirtschaftsgeschichte einer lan, Brecht, "Herkunft und Ausbildung der protestantischen Geisdich im 16. Jahrhundert," Zeitschrift für Kirchengeschichte 80 (1969): 163-75.

21. In 1549, seven of the twenty-seven pastors in rural posts had matriculated; three of these had received degrees. The participants of the first synod are listed in Emil Dürr and Paul Roth, eds., Aktensammlung zur Geschichte der Basler Reformation in den Jahren 1519 bis Anfang 153 (Basel, 1921-1950), 3:483-85 (henceforth ABR); the mames of the rural pastors in 1548 and sub-

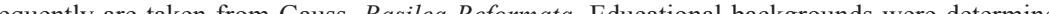
on the basis of the following published university matriculation records: H. G. Wackernagel, ed. the situation had changed dramatically. Forty years after the Reformation, twenty-two of the twenty-seven rural pastors had matriculated at Basel's university: Of these, six had obtained their bachelor's degrees, and four more had continued on to earn a master's degree. The emphasis on education only increased over time. By 1589 all twenty-eight of Basel's rural pastors had at least some university education. Fourteen of them had a B.A., eight more an M.A., and only six had left the university without finishing a degree. A generation later, a master's degree had become a virtual prerequisite for a pastoral post. Although there were still thirteen clergy who did not have master's degrees in 1609 , only two of these were young enough to have matriculated at the university after 1575, and the appointment of one of them was clearly a recognition of his family connections: both his father and his grandfather had been pastors in the city of Basel and professors at the university. ${ }^{22}$ The remaining sixteen clergy, all younger pastors, had earned their master's degrees before being appointed to their first position.

One significant result of the city's support for pastoral training was the creation of an increasingly homogeneous and territorialized pastoral corps. By the early seventeenth century, almost all of the rural pastors were the sons of Basel burghers, and many were related through blood or marriage. ${ }^{23}$ A significant proportion had lived together in the same college and had studied under the same teachers while preparing for their pastoral career. The result of such close, continual contact was the formation of a remarkably uniform and insular group of men who served the Basel church.

Because of the strong ties between Basel's university and its church, each successive generation of pastors was trained according to the theological currents that dominated Basel during his university years. During the 1530s the Basel church moved from the staunchly Zwinglian position of its first leader, Johannes Oecolampadius, to support of Martin Bucer's mediating efforts under Oswald Myconius. In 1534 the city officially issued a statement of faith,

Die Matrikel der Universität Basel, vols. 1-3 (Basel, 1951-1962) (whose entries list other universities at which individual students are known to have matriculated); Hermann Mayer, ed., Die Matrikel der Universität Freiburg im Breisgau: von 1460-1656, repr. ed. (Nendeln, Liechtenstein, 1976); Hermann Keussen, ed. Die Matrikel der Universität Köln 1389 bis 1559, 3 vols. (Bon, 1892-1951); Georg Brier, Die jüngere Matrikel der Universitut Leipzig 1559-1809, 3 vols. (Leipzig, 1909); Württembergische Kommission für Landesgeschichte, Die Matrikeln der Universität Tübingen, facsimile repr. ed. (Nendeln, Liechtenstein, 1976).

22. The pastor in question was Friedrich Koch, son of Samuel and grandson of Ulrich Koch. See the discussion in the Basel Kirchenrat about whether two candidates for the ministry recommended by the senate would be considered for posts even though they did not have master's derees, meeting of 22 June 1586, BStA Kirchen Archiv D 1, 1 (Kirchenratsprotokolle; hereafter KRP)

23. Amy Nelson Burnett, "The Basel Clergy in the Later Sixteenth Century: A Preliminary Survey," paper presented at the Sixteenth Century Studies Conference, Toronto, Ont., Canada, October 1994 
the (First) Basel Confession, adapted by Myconius from an earlier confession attributed to Oecolampadius. ${ }^{24}$

Basel's connection with Strasbourg and its openness to Lutheran theology in general increased under the leadership of Simon Sulzer, a Bucer protégé who became antistes in 1553. Despite opposition from some of the city's pastors, Sulzer kept Basel from officially endorsing the Second Helvetic Confession in $1566 .{ }^{25}$ Five years later, after a doctrinal controversy broke out among the city's ministers, all pastors in both the city and rural parishes were required to subscribe to the Wittenberg Concord along with an interpretation penned by Bucer emphasizing its Zwinglian aspects. ${ }^{26}$ Sulzer could not introduce Lutheran doctrine into the Basel church, but as its head he was able to maintain a certain degree of theological latitude in the church that distinguished it from its Reformed Swiss allies.

After Sulzer's death, the Basel church changed theological direction once again. Johann Jakob Grynaeus, the new antistes, dedicated his first decade in office to eliminating any traces of Lutheranism from the clerical corps. His efforts reached a culmination at a synod for the rural pastors held in March 1598 that was called specifically to eliminate doctrinal dissent. The synod opened with an admonition from the presiding senate representative, informing the pastors that this was their final opportunity to "receive instruction" on any controversial issues. Then Grynaeus, his chief assistant Johann Tryphius, and one of the university's theology professors, Amandus Polanus (who happened to be Grynaeus' son-in-law), went through each article of the Basel Confession, explaining its "proper" (i.e., Reformed) interpretation to the clergy. At the end of the session the pastors were asked if they accepted the Basel Confession as it had been explained to them. Not surprisingly (since rejection meant loss of a job and probable exile from their homeland), they all endorsed the confession with Grynaeus's interpretation. Two months later they were told to demonstrate their doctrinal unity by subscribing to a recently-issued ordinance that set standards of doctrine and conduct for new clergy.

At the same time that they were being pressured toward greater doctrinal uniformity, Basel's rural pastors were also increasingly subjected to closer oversight of both their personal lives and the performance of their pastoral duties. Over the course of the sixteenth century the Basel church developed a hierar-

24. On the Basel Confession and its subsequent fate, see Karl Rudolf Hagenbach, Kritische Geschichte der Entstehung und Schicksale der ersten Basler Konfession, 2nd ed. (Basel, 1857).

25. Hans Berner, "Basel und das Zweite Helvetische Bekenntnis," Zwingliana 15 (1979): 8-39.

26. Amy Nelson Burnett, "Finding the Common Ground in Confessional Conflict: The Basel Paroxysm of 1570-71," paper presented at the Frühe Neuzeit Interdisciplinär Conference, Duke University, Durham, NC, April 1995. In 1578 the requirement that new pastors subscribe to the Wittenberg Concord and its explanation was dropped. On the controversy over the Lord's Supper that broke out in Basel in 1578, see Frank Hieronymus, "Gewissen und Staatskirchentum: Basler Theologie und Zensur um 1578," Archiv für Reformationsgeschichte 82 (1991): 209-38. chical system of clerical oversight whose foundation rested on the three chapters into which the rural territory was divided. Statutes governing the rural clergy issued in 1582 gave the deans of the district chapters broad supervisory authority over the pastors in their districts. The deans were also required to hold district chapter meetings twice a year to discuss matters of pastoral concern and to discipline individual clergy if necessary. More difficult ecclesiastical or disciplinary problems were referred first to a general meeting of all rural clergy, and then to the Kirchenrat, the committee of urban pastors and senators who were ultimately responsible for ecclesiastical affairs in Basel. ${ }^{27}$ The small size of the chapters - the largest had only eleven parishes - made clerical oversight at the district level not only manageable but ultimately fairly effective in raising standards of doctrine and conduct. ${ }^{28}$ This formal supervisory structure combined with the more informal bonds of family, friendship, and common educational and professional experiences to create over time a shared sense of purpose and identity among Basel's rural pastors.

This sense of identity clearly emerges from a letter sent by the three district deans to the senate in May 1598, protesting the requirement that they subscribe to the newly-issued pastoral ordinance. The deans vigorously defended themselves and their colleagues against charges that they were divided among themselves and guilty of ignorance, offensive conduct, and neglect of duty. They acknowledged that the rural pastors were not all equally gifted in learning and abilities, but they argued that they "could all proclaim and teach what was useful from God's word." As Basel burghers they remained loyal to the city government, even through recent peasant unrest that had placed them, their wives, and their children in great danger. The deans' views of their parishioners were ambivalent. On the one hand, the peasants among whom they lived were "a coarse and unreasonable people, stiff-necked, masterless knaves," yet the clergy felt duty-bound to help those same peasants, especially "the widows and orphans," when they sought their pastor's assistance in legal or financial matters. The pastors participated in wedding feasts and other parties "for the sake of neighborliness," but they also enjoyed visiting with their brother pastors. The deans admitted that Basel's rural pastors were not perfect: in the past there had been cause for scandal, and some pastors had been guilty of spending too much time fishing, hunting birds or game, or in other pursuits. The current pastors, however, could not be accused of wasting their time in such ways. In summary, the deans concluded, the senate could be confident that the pastors were all committed to furthering "God's honor, the edification of his holy church, and our own salvation and that of our listeners ... [ [since] on the Last Day we must

27. "Ordnung vnd statuten Gemeiner Brüederen vnd Kilchendiener des Capitels im Sissgoüw vnd gantzer landschafft Basel,” BStA Kirchen Archiv HH 3.

28. Amy Nelson Burnett, "Controlling the Clergy: The Oversight of Basel's Rural Pastors in the Sixteenth Century," Zwingliana 25 (1998): 129-42. 
appear before the judgment seat of Christ, together with the sheep entrusted to us, and must give account." 29

Throughout their letter, the deans emphasized their collective consciousness as obedient subjects of the Basel senate. Nevertheless, they were not mere tools of the secular authority who unquestioningly carried out orders given to them. The deans' letter reflects a clear sense of their responsibilities as clergy accountable to God for their charges, with standards of conduct and behavior developed internally rather than simply imposed from above. Although expressed in a muted fashion in the letter, there remained at least a potential for conflict between the pastors and the secular authorities.

The letter also reflects the pastors' conviction that they had been set over and apart from their parishioners by God. Their backgrounds and education certainly separated them from the peasants among whom they lived. Under these circumstances, how effective were they at influencing the beliefs and behavior of Basel's rural subjects?

\section{Pastors and Parishioners}

The pastors' first responsibility as agents of confessionalization was to teach sound doctrine to their parishioners. The chief source of "orthodox" religious knowledge for most villagers would have been the sermons preached by their pastor on Sunday and at the mid-week service. During the late 1580s it became the practice for pastors to use the day's prescribed Gospel reading for their Sunday sermon, but they had considerable latitude in choosing the text for the mid-week sermon. In 1594, for instance, rural pastors were preaching on Genesis, Joel, Kings, Psalms, Micah, Jonah, and Ephesians. ${ }^{30}$ The contents (and pedagogical value) of the sermons could vary widely, depending not only on the Scripture chosen but on the way the texts were explained. In 1601 one pastor was rebuked for spending too much time on each passage: "[you] may want to expound in detail on the significance of the Jewish priests' clothing (he was told), [but] the illiterate won't be able to understand it; it is more necessary to preach on Christ, on rebirth, faith, and other useful things." Four years later, pastor Leonhard Strübin reported that he had preached on the Acts of the Apostles during his mid-week sermons for the past 51/2 years, and had reached Chap. $14 .{ }^{31}$ At the rate of not quite two verses per half-hour sermon, Strübin had plenty of time to expound on doctrinal issues!

Regular catechetic instruction was another concern of the pastors. The Reformation Ordinance of 1529 mandated that children between the ages of seven

29. Letter dated 20 May 1598, BStA Kirchen Archiv HH2, \#9, pp. 221-27.

30. 1594 Visitation, HStA Kirchen Akten E1; copy in Kirchen Archiv HH4, \#13.

31. Censure of Jacob Ryter, 1601 visitation, HStA Kirchen Akten E1, fo. 3r; Strübin's report, BUB, Ms G II 11: 378-81. and fourteen be examined on their knowledge of the catechism four times a year, but this was not enough to satisfy the pastors. ${ }^{32}$ At a series of synods held between $1555-59$, the pastors repeatedly requested that the senate mandate more frequent catechism instruction. ${ }^{33}$ In their 1560 response to the synodal articles, the senate refused to modify the Reformation Ordinance, ${ }^{34}$ and the matter was dropped for the remainder of Sulzer's tenure. Johann Jakob Grynaeus brought the issue up again soon after taking office, however, and by 1588 he had persuaded the senate to require monthly catechism instruction. ${ }^{35}$ Five years later the monthly catechisms were firmly established throughout Basel's territory, although the pastors were still reporting that their parishioners regarded them as an unwelcome innovation. ${ }^{36}$

Detailed sermons and frequent catechism services were of no use as pedagogical devices, however, if no one came to hear them. In the first decade after the Reformation, the rural pastors complained bitterly that few people were attending church and that the word and sacraments were despised by their parishioners. By the last third of the sixteenth century, however, the situation had improved markedly. According to the visitation reports, parishioners were coming diligently to hear the Sunday sermons, although attendance at the midweek service was not as good. Getting adults to attend the catechism services was a constant problem throughout the century, but by the 1580 s pastors were reporting that children came regularly to catechism. In addition, the pastors now recited the elements of the catechism aloud after their sermons, so that everyone heard them each week.

Given the lack of documentation coming directly from the parishioners, it is difficult to evaluate how much they learned from their pastors. Anecdotal evidence gives the impression that the peasants had mastered at least the basic elements of the catechism. In 1601, for instance, one pastor reported that the children in his new parish answered questions from the catechism so well "that he was amazed at [them]." 37

32. $A B R$ 3: 389; the 1587 visitation revealed that most pastors did indeed hold quarterly catechism services. An edict issued in 1543 provided for monthly catechism services, but this was apparently not put into practice and had been forgotten by the 1550s; Staatsarchiv Basel-Land, Kirchenbücher Liestal 1, fol. 356r, contains a copy of this edict.

33. The problem of infrequent catechization was first brought up in the 1555 synodal articles, BStA Kirchen Akten A9, fol. 394r-96r. In 1557 the synod asked the senate to consider whethe catechism services should be held more frequently, BStA Kirchen Akten C3: 86r-87r. In 1558 and 1559 the synod recommended that catechism instruction be given in each parish church before its bimonthly communion service and that pastors should test the schoolchildren's knowledge of the catechism once a month, BStA Kirchen Akten C3: 88r-89v, 66r-74v.

34. BStA Kirchen Akten C3: 82r.

35. KRP, BStA Kirchen Archiv D 1,1: 7 June 1588; see entry describing the introduction of the monthly catechism service, 69 .

36. 1593 General Chapter, BStA Kirchen Archiv A24, \#4; copy in KRP, BStA Kirchen Archiv D 1,1:251ff. Some of the pastors reported that they held catechism instruction every two weeks.

37. Pastor Ezechiel Falkeysen of Langenbruck, 1601 visitation, BStA Kirchen Akten E1, fol. 15r 
Popular resistance to Grynaeus's attempt to modify Basel's catechism also implies that Basel's rural population had indeed learned the earlier form. In Grynaeus's eyes, part of establishing pure doctrine in Basel entailed replacing the traditional numbering of the Ten Commandments used by Oecolampadius (as well as by both Catholics and Lutherans) with the Reformed numbering, which separated the injunctions "thou shalt have no other gods" and "thou shalt not make a graven image" into two commandments and combined all the prohibitions against coveting into one "long" tenth commandment. ${ }^{38}$ Although Grynaeus began his campaign for the "correct" division of the Commandments soon after assuming the leadership of the Basel church in 1586, the pastors were still encountering opposition to the new form as late as $1601 .{ }^{39}$ Adults in particular had a hard time remembering the "long" tenth commandment, and they resented the change, complaining that "their ancestors also knew how to pray, and now they're being burdened with this longer form." 40 Several pastors gave up entirely on the new division of the Decalogue, while others concentrated their effort on teaching it to the younger generation, with eventual success. As Heinrich Strübin stated with some pride in 1605 ,

I began twenty years ago to explain [the Decalogue] in the weekday sermons and pointed out the errors of the popes and others and began to teach the youth the right division, and although I have had to listen to and swallow many absurdities from young and old, as if I've introduced some novelty and so forth, I didn't quit and I let such talk go in one ear and out the other and continued for as long as God has given me his grace and his Spirit, so that I brought a few boys and girls to my side (and gradually have brought around the rest, God be praised), and since then both young and old, and even the parents, have been well-pleased and content. ${ }^{41}$

The problems the pastors faced in teaching a new division of the Commandments says something about their predecessors' successes in instilling sound doctrine. The older generation of villagers had evidently learned the traditional form well enough to recognize - and to resent - what they viewed as unjustified innovations. Their reluctance to change was not based on specific

38. On the numbering of the Decalogue in the various editions of Basel's catechisms over the sixteenth century, see Bo Reicke, Die zehn Worte in Geschichte und Gegenwart: Zählung und Bedeutung der Gebote in den verschiedenen Konfessionen (Tübingen, 1973), 17-20.

39. See the discussion of the "correct division of the Decalogue" in the KRP, BStA Kirchen Archiv D 1,1: 13 January 1587; discussion of the Decalogue at the 1598 General Convent, BUB MsKiAr 22c, \#4, fo. 34r-37r; .1601 visitation report, BStA Kirchen Akten E1.

40. 1598 General Convent, BUB MsKiAr 22c, \#4, fo. 35r. See the 1601 visitation, in which Dean Gabriel Hummel reported that his congregation still used the older phrases when they recited the Decalogue, Creed, and Lord's Prayer, BStA Kirchen Akten E1, fol. 4v.

41. BUB, G II 11: 378-81. Pastor Ulrich Meyer also reported some success "among the young people who have learned the long tenth commandment and other articles;" 1601 visitation, BStA Kirchen Akten E1, fol. 13v. confessional identity so much as on general adherence to Basel tradition, in this case a catechism attributed to Oecolampadius. ${ }^{42}$ Having accepted one of the principles introduced with the Reformation, the need to know the basic elements of the catechism, they were apparently loath to accept a change in what had become familiar. The change in numbering of the Commandments was, after all, a fairly minor point for Basel's rural parishes in the 1590s. Although it gave theological justification for the Reformed insistence on the elimination of images from the church, this had long ceased to be an issue in Basel's territory, since most images had been removed from the rural churches at the time the Reformation was adopted. ${ }^{43}$ However, the original division of the Commandments was associated with Oecolampadius, the "father" of Basel's Protestant Church, and by adopting the new numbering the church's leaders were abandoning a local tradition in favor of a position shared by the larger Reformed community.

Another indirect indication of the Protestant identity of Basel's rural subjects is the popular resistance to the reintroduction of Catholicism by the bishop of Basel after several villages that had been under Basel's protection were returned to his jurisdiction in 1585. The inhabitants of these villages almost unanimously rejected the bishop's attempts to reintroduce the mass, although this meant disobeying their legitimate secular ruler. The bishop's slow and steady efforts, including the expulsion of the Protestant clergy and the replacement of Protestant village officials with Catholic ones, eventually succeeded, but it took a generation before a strongly Catholic identity could be established in these villages. ${ }^{44}$

One significant development within the Basel church after the introduction of the Reformation was the clergy's expectation that the laity should not only be able to recite correct doctrine, but also that they internalize it. In his notes prepared for the synod held in May 1597, Grynaeus included a list of questions asking the pastors about the spiritual state of the sick and those on their

42. This is the explicit reason that pastor Jacob Ryter gave for his opposition to changes in the catechism during the synod of rural pastors in 1598 described above; BUB MsKiAr 22c, \#4, fol. $23 \mathrm{r}-27 \mathrm{r}$.

43. The notable exceptions, because they were the subject of a power struggle between the city pastors and the senate in the summer of 1597, were the statues of St. George and St. Martin on the facade of the Basel cathedral; KRP, BStA Kirchen Archiv D 1,1: 26 July, 1597 et seq. This conflict between urban pastors and senate had no impact on the rural territories, however. In contrast, popular reaction to attempts by ruler and pastors in the empire to impose Reformed doctrine and litury couldion to and litury coul mer practices were more marked; see the reaction of the parishioners of Sonnenborn, Heinz Schilling, "Between the Territorial State and Urban Liberty: Lutheranism and Calvinism in the County of Lippe," in The German People and the Reformation, ed. R. Po-chia Hsia (Ithaca; 1988), 263-83, here at $272-73$.

44. Karl Gauss, "Therwil und Ettingen in der Zeit der Reformation und Gegenreformation," Basler Jahrbuch (1925): 107-62; idem, "Die Gegenreformation im baslerisch-bischöflichen Laufen," Basler Jahrbuch (1918): 31-75. 
deathbeds, and whether they could tell if "some were improved through their sermons and others were hardened." 45 Similar questions were asked four years later in the visitation of 1601, and most of the pastors gave favorable reports about their parishioners. Large numbers had received the Lord's Supper at Easter, and their congregations remained in church while baptisms were performed. In particular, the pastors reported that when they visited the sick they found many who were "well-instructed" or "able to be consoled.",46

As can be inferred from the above, Basel's pastors expected that their parishioners' knowledge of correct doctrine would lead them to live sober, godly lives as befitted proper Christians. The synodal records from the first decade after the adoption of the Reformation are full of complaints about the conduct of Basel's rural subjects: they were guilty of blasphemy, swearing, drunkenness, gambling, dancing, and especially of disrespect for God's word, for the sacraments, and for the pastors themselves. The clergy were also critical of the district and local officials for not doing their duty by taking vigorous action against vice

These frustrations stemmed in part from the fact that the pastors had no independent power to discipline their parishioners directly. Instead, the Basel ban ordinance, issued in December 1530, authorized the district governor (Obervogt) to appoint two "ban brothers" from each village who would be responsible for the oversight of the parishioners together with their pastor. The magistrate revised the ban ordinance several times over the next few years in an effort to increase both the authority of the ban brothers and their willingness to perform their duties, as well as to make the procedure for disciplining sinners more effective. ${ }^{47}$ These revisions gave the pastors a voice in the selection of the ban brothers and provided for the referral of contumacious sinners first to the Obervogt, then to the senate in the city. The ban brothers were also required to meet weekly in order to determine whether anyone in the village was guilty of "dishonorable" conduct and to admonish offenders to reform. ${ }^{48}$

\section{BUB MsKiAr 22b: 312-13.}

46. BStA Kirchen Akten E1; I have inferred the questions from the similar responses given by the pastors in the visitation report. See for example the reports of Isaac Keller, Rothenfluh, fol. 8v, and Ulrich Meyer, Waldenburg, fol. 13v.

47. ABR 5:236-37, \#267 (10 June 1531); 6:186-87, \#222 (22 December 1532); BUB MsKiAr 22a, \#34 (7 August 1538), edict concerning ban and visitation; BUB MsKiAr 22a, \#35 (19 November 1539), synod and ban ordinge? BUB MsKiAr 22a, 440 (12 August 1540), Acta Liechsten sia: reissue of earlier morals edicts; BStA Kirchen Akten A9: 375v-376v (23 September 1542), Verbesserung der Bannordnung.

48. The ban brothers of Basel's rural territories were similar in composition and function to the Stillstand in Zurich's rural parishes and the Chorgericht in Bern's rural territories. On the Zurich Stillstand, see Bruce Gordon, "Die Entwicklung der Kirchenzucht in Zurich am Beginn der Reformation" in Kirchenzucht und Sozialdisziplinierung im frühneuzeitlichen Europa (mit einer Auswahlbibliographe), el. Heinz Schilling (Berin, 1994), 65-90; on the Benese Chorgerich A see Heinich Richard Sch. "Ge Sozialdisziplinierung und kommunaler Selbstregulation," in Bäuerliche Frömmigkeit und kommunale Reformation, ed. Hans von Rütte, Itinera 8 (Basel, 1988), 85-121.
It took some time for the ban ordinance to become an effective means of enforcing ecclesiastical discipline. The pastors' first task was to persuade their parishioners that secular punishment did not obviate the exercise of church discipline. The 1542 revision of the ban ordinance stated that sinners punished by the Obervogt were also to be reconciled with the church, and in order to keep clear the distinction between "the magistrate's sword, [which is] civil punishment" and "the church's sword, which uses the holy word of God to punish in the spirit of mildness," it specified that no one could serve as secular official and as ban brother concurrently. ${ }^{49}$ Basel's subjects apparently did not appreciate this distinction between the two swords, however. In 1558, the pastors were still complaining that their parishioners asked "why it was necessary to be reconciled before the church [when] this has already happened before the magistrate or the Obervogt,' as if that were sufficient by itself and the church didn't have its own special power." 50

The pastors also had problems persuading the ban brothers to cooperate in the task of church discipline. Even as late as 1590, one minister reported that the ban brothers of his parish refused to report the sins of their fellow villagers, because if they did, they would be reviled as informers. ${ }^{51}$ The negligence of local officials in enforcing the city's morals code presented yet another difficulty for the pastors. When they admonished their secular counterparts to better performance of their duties, the officials were offended and claimed that the pastors had no right or power to do so. The peasants challenged the pastors' authority on another issue as well: although it was the general practice for the clergy to proclaim new or reissued edicts from the pulpit, the peasants refused to recognize edicts that imposed fines or other punishment unless the Obervogt had a written record of the edict. ${ }^{52}$ The pastors thus had little authority to punish sin or exercise church discipline without the cooperation of the ban brothers and the secular officials on both the village and district levels.

Over time, however, the cooperation between pastors, ban brothers, and other local officials gradually improved. The visitors sent to inspect Basel's rural churches in 1601 heard few complaints concerning either the performance

49. Acta Liechstalensia, BUB MsKiAr 22a \#40, fo. 291r-v.

50. BStA Kirchen Akten C3: 90r-v.

51. “... werden sie Kallthansen geschallten;” as reported by pastor Philip Lautenberg of Muttenz; protocol of 1590 General Chapter meeting, KRP, BStA Kirchen Archiv D 1,1: 162. According to Grimm's Wörterbuch, in sixteenth-century Switzerland a "Kalthans" was more than simply a "snitch" but could also be a public official who reported moral offenders to the authorities (vol. 5, col. 91). In his study of elders in the county of Nassau-Dillenberg, Paul Munch points to the fear of social isolation as one reason for the reluctance of elders to carry out their duties, "Kirchenzuch und Nachbarschaft: Zur sozialen Problematik des calvinistischen Seniorats um 1600," in Kirche und Visitation: Beiträge zur Erforschung des frühneuzeitlichen Visitationswesens in Europa, ed. Ernst Walter Zeeden and Peter Thaddäus Lang (Stuttgart, 1984), 216-48.

52. See the complaints concerning these points made at the 1558 synod; BStA Kirchen Akten F6, \#6. 
of secular officials and ban brothers or the enforcement of the ban ordinance. The most serious charge was made by pastor Leonhard Soerin, who accused the ban brothers of "want[ing] to spare everyone; when he [Soerin] said anything, they excused themselves before the peasants and blamed him for it." On the other hand, several pastors stated that the ban brothers of their parish met regularly with them or simply reported that the ban ordinance was enforced. ${ }^{53}$ Even when the pastors expressed their frustrations with the ban brothers, their complaints were more likely to stem from a difference in clerical and lay perceptions concerning the degree of moral oversight the ban brothers were expected to exercise than from the ban brothers' complete disregard for their duties. At the 1605 meeting of the clergy in the Waldenburg district, for instance, Ulrich Meyer complained about the negligence of the ban brothers in his parish, but at the end of the meeting he asked his fellow pastors whether these same ban brothers should be compensated out of the chapter treasury when their meetings lasted longer than an hour, particularly since some of them had a long way to go on their return home. ${ }^{54}$ The willingness of the ban brothers to endure lengthy meetings is a testimony to the seriousness with which they undertook their duties, despite their pastor's complaints about them.

\section{Clergy and Confessionalization}

Higher qualifications for the pastorate, improved oversight of the laity, and stricter enforcement of the ban ordinance and morals code eventually had an impact on rural parish life. At the end of the sixteenth century, the pastors still complained about certain offenses such as swearing, dancing, and ostentatiousness at weddings, but complaints about the parishioners' disrespect for religious observances and for the pastor's authority virtually disappear. As mentioned above, by the last quarter of the century the villagers were attending worship, and they turned out in large numbers to receive the sacrament on the appointed days. Their diligence in attending the Sunday sermons was due at least in part to strict enforcement of the senate's mandate requiring church attendance, as is inferred from the frequent requests made to visitation officials that the mid-week services be suspended during the busy haying and harvest season. In return, the peasants promised that they would be even more conscientious in coming to church on Sunday. If the church attendance mandates were not being enforced, the villagers would hardly have worried about skipping the mid-week service.

Perhaps more significant, however, was the gradual raising of the standards of belief and behavior to which Basel's rural population was held. By 1601 the pastors had much higher expectations concerning both the doctrinal

53. 1601 visitation report, BStA Kirchen Akten E1, citation at fol. 7v.

54. Protokolle of the Waldenburg district chapter, BStA Kirchen Archiv HH 14, 1:20, 23-24. knowledge and the conduct of their parishioners than did their predecessors in the first decade after the Reformation. Earlier laments that the villagers did not know how to pray give way to complaints that they did not want to learn the new numbering of the Commandments; reports that parishioners were not attending the sermons are replaced by statements that the benefits of sermon attendance "appear in some more than in others." The laity were expected not only to know doctrine but to draw comfort from that knowledge in times of sickness or death. The higher standards reflected in these visitations were not unique to Basel or to the Reformed Church. The types of questions asked in visitation records indicate that similar changes over time occurred in Catholic areas, while the visitation ordinances in Electoral Saxony evolve from efforts to eliminate vestiges of Catholicism in the 1520-30s to a concentration on the behavior of parishioners in the $1570-80 \mathrm{~s}^{55}$

The changing nature of the pastors' complaints indicates that there was a significant improvement in at least the external conformity of Basel's rural subjects to the church's religious standards over the course of the sixteenth century. ${ }^{56}$ It also presents a picture of religious life in Basel's rural parishes similar to that found in Strasbourg's countryside at the end of the century, where visitation reports depict a low incidence of religious dissent, satisfactory knowledge of the catechism, and the development of a popular Protestant religious culture. ${ }^{57}$ The parallel with Strasbourg is particularly instructive, since the imperial city and the Swiss city-republic shared some important characteristics, such as a small rural territory that could be easily supervised, the presence of an academy or university to train local students for the pastorate, and the consequent formation of a well-trained and socially homogeneous pastoral corps. ${ }^{58}$

The key role played by the ban brothers and the local officials reveals the importance of cooperation between pastors and at least some of their parishioners in establishing and enforcing the new standards of behavior. Without the

55. Peter Thaddäus Lang, "Reform im Wandel: Die katholischen Visitationsinterrogatorien des 16. und 17. Jahrhunderts," in Kirche und Visitation, ed. Zeeden and Lang, 131-90; Susan Karant-Nunn, "Neoclericalism and Anticlericalism in Saxony, 1555-1675," Journal of Interdisciplinary History 24 (1994): 615-37.

56. Bernard Vogler also concludes that the great majority of Protestants in the Palatinate conformed, at least externally, to the church's expectations, although he points out that this does not mean that they had internalized Protestant values; "Die Entstehung der protestantischen Volksfrömmigkeit in der rheinischen Pfalz zwischen 1555 und 1610," Archiv für Reformationsgeschichte 72 (1981): 158-95.

57. James M. Kittelson, "Successes and Failures in the German Reformation: The Report from Strasbourg," Archiv für Reformationsgeschichte 73 (1982): 153-74, and idem, "Visitations and Popular Religious Culture: Further Reports from Strasbourg," in Pietas et Societas: New Trends in Reformation Social History. Essays in Memory of Harold J. Grimm, ed. Kyle C. Sessions and Phillip N. Bebb (Kirksville, Mo., 1985), 89-102.

58. On the Strasbourg clergy, see Vogler, "Recrutement et carrière." 
support of the ban brothers, the Basel pastors had little direct authority over their parishioners beyond moral suasion. They could use that moral suasion to good effect, however, by backing the authority of the ban brothers and the secular officials. In his study of the Bernese Chorgericht, Heinrich R. Schmidt has argued that Reformed standards of conduct could not simply be imposed on a community by a pastor who was an outsider. Instead, the Chorgericht's authority grew out of each community's acceptance and internalization of the Reformed emphasis on moral behavior. ${ }^{59}$ Both Bruce Tolley in his study of Württemberg and Thomas Robisheaux in his examination of Hohenlohe have also pointed out that church discipline was more likely to be effective when certain groups within the village agreed with the clergy concerning standards of moral behavior. ${ }^{60}$ The same can be said about the relations between clergy and lay officials in Basel's villages: it may have taken two or three generations, but by the end of the century the pastors and the ban brothers in most of Basel's rural parishes seem to have agreed on what those standards were and for the most part they worked together to enforce them. Whether those standards coincided with the expectations of the ecclesiastical and secular authorities in the city is another question, and one that cannot be answered on the basis of the visitation reports: what the visitors did not ask about, the pastors and local officials did not volunteer.

Moreover, the picture of external religious conformity must be balanced by the Basel pastors' continued complaints about their parishioners' behavior. The pastors had little success in their attempts to eliminate established elements of popular culture, such as the festivities surrounding weddings or parish festivals and the use of magical practices - although with regard to magic there may have been a change in outlook, since, according to one pastor, the parishioners justified it "by saying it happened with God's word." ${ }^{1}$ The failure of the Protestant clergy to uproot such behavior has been well-documented in studies of

59. H. R. Schmidt, "Gemeinde-Reformation;" see also his "Die Christianisierung des Sozialverhaltens als permanente Reformation: Aus der Praxis reformierter Sittengerichte in der Schweiz wahrend der frühen Neuzeit," in Kommunalisierung und Christianisierung in Mitteleuropa: Voraussetzungen und Folgen der Reformation, 1400-1600, ed. Peter Blickle and Johannes Kunisch, 113-63 (Berlin, 1989).

60. Bruce Tolley, Pastors and Parishioners in Württemberg During the Late Reformation, 1581-1621 (Stanford, 1995), 111-12; Thomas Robisheaux, "Peasants and Pastors: Rural Youth Control and the Reformation in Hohenlohe, 1540-1680," Social History 6 (1981): 281-300.

61. 1601 Visitation, BStA Kirchen Akten E1, fol. 7v. According to Eva Labouvie, peasants in the Saarland also used this defense of popular magic in reaction to official condemnation of such practices by the church, "Wider Wahrsagerei, Segnerei und Zauberei: Kirchliche Versuche zur Ausgrenzung von Aberglaube und Volksmagie seit dem 16. Jahrhundert," in Verbrechen, Strafen und soziale Kontrolle, ed. Richard van Dülmen (Frankfurt am Main, 1990), 15-55. The church's struggle against popular magic is a topic that goes beyond the limits of this paper; for a broader discussion of the issue, see Eva Labouvie, Verbotene Künste: Volksmagie und ländlicher Aberglaube in den Dorfgemeinden des Saarraumes (16.-19. Jahrhundert) (St. Ingbert, 1992) other areas and has generated much debate among English-speaking scholars about the success or failure of the Reformation as a whole. ${ }^{62}$ The Basel example suggests that a more fruitful approach would be to consider the interaction between pastor and parishioners as one of negotiation, compromise, and accommodation: certain elements of the clergy's program, particularly those concerning basic religious doctrines and practices, were accepted by Basel's rural subjects, while others were ignored. ${ }^{63}$

The degree to which Basel's subjects accepted their pastors' program in turn has implications for assessing the effectiveness of the clergy as mediators of confessional and social discipline over the course of the sixteenth century. Basel's rural pastors gradually moved from a broad evangelical identity and loyalty to Oecolampadius as the founder of Basel's church to adoption of more specifically Reformed doctrine, acceptance of the higher standards of conduct expected of Protestant clergy, and a growing sense of their professional solidarity and commitment to their pastoral duties. The transformation of Basel's pastoral corps in turn aided them in bringing about concrete changes in the level of doctrinal knowledge among the city's rural subjects and, at least to some extent, in their religious observances as well. In their efforts to eliminate other aspects of popular culture, however, the clergy were not so successful. The peasants were neither powerless against pressures from above, nor were they simply the passive subjects of official efforts to impose greater confessional and social discipline. The example of Basel's rural clergy thus reminds us that generalizations about the process and the effectiveness of confessionalization need to be tied more closely to our knowledge of religious and social change at the local level. Only then can it serve as a useful construct for understanding the long-term changes in early modern European society in the wake of the Reformation.

62. To list only a few recent studies on the long-term effect of the Reformation, see Siegfried Müller, "Die Konfessionalisierung in der Grafschaft Oldenburg: Untersuchungen zur 'Sozialdisziplinierung' einer bäuerlichen Gesellschaft in der Frühen Neuzeit," Archiv für Reformationsgeschichte 86 (1995): 257-319; C. Scott Dixon, The Reformation and Rural Society: The Parishes of Brandenburg-Ansbach-Kulmbach, 1528-1603 (Cambridge, 1996), 102-42; on the success/failure debate, see n. 5 above.

63. See Heinrich R. Schmidt's overview of research on the impact of confessionalization, where he points out that "the 'selective acceptance' of confessionalization efforts has been especially poorly examined," Dorf und Religion: Reformierte Sittenzucht in Berner Landgemeinden der Frühen Neuzeit (Stuttgart, 1995), 95-102; citation at 102 